\title{
PENEGAKAN HUKUM TERHADAP TINDAK KEKERASAN YANG DILAKUKAN OLEH SUAMI TERHADAP ISTRI
}

\author{
Made Warka \\ Fakultas Hukum Universitas 17 Agustus 1945 Surabaya \\ e-mail:warka_dpk@ymail.com \\ Dariati \\ Fakultas Hukum Universitas 17 Agustus 1945 Surabaya \\ e-mail: dariati_fh17@yahoo.co.id
}

\begin{abstract}
ABSTRAK
Peristiwa kekerasan dalam rumah tangga di Indonesia yang menjadi korban adalah perempuan (istri). Kekerasan dalam rumah tangga berkaitan erat dengan persoalan gender, adanya diskriminasi terhadap perempuan, serta diidentikkan dengan permasalahan pribadi dalam suatu keluarga. Kekerasan yang dilakukan oleh suami terhadap istri bukan hanya kekerasan fisik, tetapi juga kekerasan psikis, ekonomi dan seksual. Dalam mengantisipasi hal tersebut perlu mengetahui dan melakukan penelitian secara mendalam mengenai pengaturan hukum kekerasan yang dilakukan oleh suami terhadap istri, serta faktor-faktor terjadinya kekerasan yang dilakukan oleh suami terhadap istri, dan upaya penanggulangannya. Karya ilmiah ini merupakan penelitian normatif, bahan hukum terkait digunakan untuk mempelajari dan menganalisis secara sistematis, peraturan perundang-undangan (Undang-Undang Nomor 23 Tahun 2004 tentang Penghapusan Kekerasan Dalam Rumah Tangga). Diharapkan penegakan hukum terhadap kekerasan yang dilakukan oleh suami terhadap istri dapat dilaksanakan secara maksimal. Baik dengan melakukan penanggulangan secara penal maupun non penal. Sehingga hambatan-hambatan dalam penyelesaian kekerasan yang dilakukan oleh suami terhadap istri dapat ditanggulangi.
\end{abstract}

Kata Kunci: kekerasan dalam rumah tangga, penegakan hukum.

\begin{abstract}
Households violence victims in Indonesia are commonly women (wives). Household violence is closely related to gender, discrimination against women, and identified with personal problems in a family. Violence by husbands against wives are not only physical, but also psychological, economic and sexual violence. In anticipation of the need to know and in-depth study of the legal regulation of violence by husbands against wives, as well as the factors of violence that committed by a husband against his wife, and the overcome efforts. This research is normative research, relevant legal materials used to study and systematically analyze the regulation (Act No. 23 Year 2004 of the Elimination of Households Violence). it is expected that law enforcement of violence by husbands against wives might be optimally done. Either by reduction in the penal and non-penal. So that obstacles in the completion of violence by husbands against wives can be solved.
\end{abstract}

Keywords: households violence, law enforcement. 


\section{PENDAHULUAN}

Kekerasan yang dilakukan suami terhadap istri sering terjadi, faktanya satu dari tiga istri pernah mengalami kekerasan dalam rumah tangga. ${ }^{1}$ Ada anggapan yang tumbuh dalam masyarakat yaitu rumah tangga adalah urusan pribadi dan yang terjadi didalamnya adalah bukan urusan orang lain.

Tindak kekerasan dalam masyarakat sebenarnya bukan suatu hal yang baru. Kekerasan sering dilakukan bersama dengan salah satu bentuk tindak pidana, seperti yang diatur dalam Kitab UndangUndang Hukum Pidana (selanjutnya disebut KUHP) misalnya pencurian dengan kekerasan (Pasal 365 KUHP), perkosaan (Pasal 285 KUHP) dan seterusnya. Tindak pidana tersebut dilakukan dengan kekerasan atau ancaman kekerasan, sedangkan cara bagaimana kekerasan dilakukan atau alat apa yang dipakai masing-masing tergantung pada kasus yang timbul. Perbuatan tersebut dapat menimpa siapa saja, baik laki-laki maupun perempuan, dari anakanak sampai dewasa. Yang menarik perhatian publik adalah kekerasan yang menimpa kaum perempuan (istri), dimana pelaku dan korban berusaha untuk merahasiakan perbuatan tersebut dari pandangan publik. $^{2}$

Sejarah umat manusia telah membuktikan bahwa selama ini kaum wanita hampir selalu menjadi kaum yang dinomorduakan jika dibandingkan dengan kaum pria. Pada akhirnya mengakibatkan kaum wanita dalam kehidupan seharí-hari, banyak mengalami pembatasan yang dikenakan oleh masyarakat sendiri secara umum. Dalam hal ini wanita mendapatkan rintangan untuk mengembangkan eksistensi dan potensi yang ada pada diri mereka masing-masing, wanita menerima perbedaan kodrati antara pria dan wanita sebagai hikmah dan memahami kondisi hidup antara pria dan wanita memang berbeda, akan tetapi perlakuan yang bersifat diskriminasi terhadap kaum wanita dalam berbagai bidang kehidupan bermasyarakat berlangsung telah lama dan sangat kental.

Sampai saat ini Indonesia belum mempunyai statistik nasional untuk tindak Kekerasan Dalam Rumah Tangga (selanjutnya disebut dengan KDRT). Pencatatan data kasus KDRT dapat ditelusuri

lib.atmajaya.ac.id/default.aspx?tabID $=61 \&$ $\mathrm{src}=\mathrm{a} \& \mathrm{id}=210509$, akses tanggal 18 Mei 2011.

${ }^{2}$ Hadiati Moerti Soeroso, Kekerasan dalam Rumah Tangga, Sinar Grafika, Jakarta, 2010, h. 1. dari sejumlah institusi yang layanannya terkait sebagaimana diatur dalam Undang-Undang Nomor 23 Tahun 2004 tentang Penghapusan Kekerasan Dalam Rumah Tangga (selanjutnya disebut UU Penghapusan KDRT dan Peraturan Pemerintah Nomor 4 Tahun 2006 tentang Penyelenggaraan dan Kerjasama Pemulihan Korban Kekerasan Dalam Rumah Tangga. Komisi Nasional Anti Kekerasan Terhadap Perempuan (selanjutnya disebut Komnas Perempuan), mencatat bahwa di tahun 2006 sebanyak 22.512 kasus kekerasan terhadap perempuan dilayani oleh 258 lembaga di 32 Propinsi di Indonesia 74\% diantaranya kasus KDRT dan terbanyak dilayani di Jakarta (7.020 kasus) dan Jawa Tengah (4.878 kasus). ${ }^{3}$ Lembaga-lembaga tersebut termasuk Ruang Pelayanan Khusus (selanjutnya disebut RPK) atau Unit Perlindungan Perempuan dan Anak di Kepolisian, Pusat Krisis Terpadu \& Pusat Pelayanan Terpadu (selanjutnya disebut PKT \& PPT) di Rumah Sakit atau Layanan Kesehatan, Women's Crisis Centre (selanjutnya disebut WCC) dan Lembaga Bantuan Hukum (selanjutnya disebut LBH) yang menyediakan layanan pendampingan bagi Korban serta Kejaksaan, Pengadilan Negeri dan Pengadilan Agama.

Data tahun 2007 menunjukkan bahwa Mitra Perempuan WCC mencatat $87 \%$ dari perempuan korban kekerasan yang mengakses layanannya yang mengalami KDRT, dimana pelaku kekerasan terbanyak adalah suami dan mantan suaminya (82,75\%). Fakta tersbut juga menunjukkan 9 dari 10 perempuan korban kekerasan yang diampingi WCC mengalami gangguan kesehatan jiwa, 12 orang pernah mencoba bunuh diri; dan 13,12\% dari mereka menderita gangguan kesehatan reproduksinya.

Pada dasarnya pernikahan adalah sama yaitu membentuk suatu keluarga yang bahagia dan kekal serta membangun, membina dan memelihara hubungan kekerabatan yang rukun dan damai di samping untuk memperoleh keturunan. Sesuai dengan Pasal 1 ayat (1) Undang-Undang Nomor 1 Tahun 1974 tentang Perkawinan menegaskan bahwa perkawinan merupakan ikatan lahir batin antara seorang pria dengan seorang wanita sebagai suami istri dengan tujuan membentuk keluarga

\footnotetext{
${ }^{3}$ Komisi Nasional Anti Kekerasan Terhadap Perempuan, Catatan Tahunan tentang Kekerasan terhadap Perempuan, Jakarta, 7 Maret 2007, h. 5.
} 
(rumah tangga) yang bahagia dan kekal berdasarkan Ketuhanan Yang Maha Esa.

Penganiayaan terhadap istri hakikatnya adalah perwujudan dari ketimpangan terhadap relasi kekuasaan antara laki-laki dan perempuan di dalam masyarakat yang berkembaang (yang sering disebut sebagai ketimpangan gender), yang secara sosial menempatkan laki-laki lebih unggul dibandingkan dengan perempuan. Bahwa ketimpangan tersebut yang diperkuat oleh keyakinan sosial seperti mitos (kepercayaan terhadap masyarakat jaman dahulu yang dianggap sebagai kebenaran), dan prasangka yang menumbuhsuburkan praktik-praktik diskriminasi terhadap perempuan (baik di ranah domestik maupun publik). Dan penganiayaan yang mengakibatkan penderitaan perempuan baik secara fisik, mental maupun seksual. ${ }^{4}$

Dalam konteks kekerasan terhadap istri banyak akar kepercayaan yang berasal dari interpretasi ajaran agama yang mempertimbangkan bahwa kekuasaan suami adalah absolut terhadap istrinya, serta status subordinasi perempuan. Karena normanorma ini orang cenderung tidak mengambil jalur hukum ketika mengalami penganiayaan dalam rumah tangga.

Menurut pengamatan penulis, kekerasan dalam rumah tangga setiap tahun semakin meningkat baik kuantitas maupun kualitasnya. Disamping itu pula, hak asasi manusia khususnya perlindungan terhadap rumah tangga semakin diperjuangkan seperti munculnya kelompok kerja Convention Watch, Kompas Perempuan, Komnas HAM yang telah berupaya dan berjuang untuk menghapuskan bentuk-bentuk tindak kekerasan terhadap perempuan dan mencari alternatif pemecahannya (suatu tinjauan hukum) dan lain-lain. Puncak perjuangan tersebut dengan ditandai dengan lahirnya UU Penghapusan KDRT.

Berdasarkan argumentasi tersebut, penulis tertarik untuk meneliti secara mendalam bagaimana solusi yang tepat untuk menghapus kekerasan dalam rumah tangga, faktor-faktor apa yang menyebabkan kekerasan yang dilakukan suami terhadap istri, bagaimana perlindungan hukum terhadap korban kekerasan yang dilakukan suami terhadap istri, dan sejauhmana UU Penghapusan KDRT memberikan sanksi terhadap pelaku kekerasan yang dilakukan

\footnotetext{
${ }^{4}$ Ahmad Suaedy, Kekerasan dalam Perspektif Pesantren Gresindo, Jakarta, 2000, h. 82.
}

suami terhadap istri, dan hambatan-hambatan dalam penanganan kekerasan yang dilakukan suami terhadap istri.

\section{PERUMUSAN MASALAH}

Berdasarkan pada uraian latar belakang di atas dikemukakan permasalahan bagaimana penegakan hukum terhadap tindakan kekerasan yang dilakukan oleh suami terhadap istri.

\section{METODE PENELITIAN}

Jenis pendekatan yang digunakan dalam penelitian adalah pendekatan perundang-undangan (the statute approach) dan pendekatan konsep. Bahan-bahan hukum yang telah disusun secara sistematis selanjutnya dianalisis dengan teknik deskripsi dan argumentasi. ${ }^{5}$ Penelitian hukum adalah suatu proses untuk menemukan aturan hukum, prinsip-prinsip hukum, maupun doktrin-doktrin hukum guna menjawab isu hukum yang dihadapi. Isu hukum mempunyai posisi yang sentral di dalam penelitian hukum sebagaimana kedudukan masalah di dalam penelitian lainnya karena isu hukum itulah yang harus dipecahkan di dalam penelitian hukum sebagaimana permasalahan yang harus dijawab dalam penelitian bukan hukum. ${ }^{6}$

Metode penelitian merupakan cara untuk mencapai suatu tujuan sehubungan dengan itu, dalam penerapan ditempuh langkah-langkah sebagai berikut: Penelitian yang akan dilakukan adalah penelitian hukum normatif yang didasarkan pada bahan hukum primer, sekunder, dan tersier yaitu inventarisasi peraturan mengacu kepada normanorma yang terdapat dalam peraturan perundangundangan. Dalam hal ini berkaitan dengan kekerasan yang dilakukan oleh suami terhadap istri, selain itu juga dipergunakan bahan-bahan tulisan yang berkaitan dengan persoalan ini.

\section{PEMBAHASAN}

Berkaitan dengan adanya teori kekerasan yang mendasarkan pola pemikirannya atas fenomena kekerasan individu, maka terdapat dua teori besar yang mencoba mencerna tentang keberadaan kekerasan pada diri seseorang. Kedua teori tersebut antara lain adalah teori kekerasan sosio-anthropologis

${ }^{5}$ Rianto Adi, Metodologi Penelitian Sosial dan Hukum, Edisi I, Granit, Jakarta, 2004, h. 92.

${ }^{6}$ Ibid, h. 14. 
dan teori kekerasan genetika. Pertama, Teori sosioanthropologi, menyatakan bahwa manusia itu adalah serigala bagi manusia yang lain (homo homini lupus). Bagi Hobbes, dan tentu saja hingga kini masih sangat diyakini oleh para pengikutnya, dalam diri seseorang senantiasa bersemayam benih-benih kekerasan. Manusia, manakala diganggu kepentingannya, maka ia akan menyerang. Sedangkan kalau memiliki suatu kemauan atau kehendak, maka manusia tersebut tak tanggung-tanggung lagi untuk menyerbunya dan merampasnya kalau ada insan lain yang memiliki apa yang dimauinya itu. Perilaku agresif ini dibenarkan oleh Sigmmund Freud dengan menegaskan bahwa agresifitas yang dimiliki manusia sebenarnya bersifat bawaan dan tak terelakkan. Ia akan semakin dominan dalam kehidupan manusia sehingga pada akhirnya naluri thanatos atau daya mematikan akan melebihi naluri eros atau daya menghidupkan. Kedua, Sedangkan teori genetik, merupakan konsep teori yang diambil dari sisi ilmiah. Teori ini menyatakan bahwa kekerasan merupakan hasil suatu rangkaian reaksi kimiawi yang terjadi dalam fungsi otak seseorang. Ini terjadi karena suatu zat tertentu, serotinin, kurang pasoknya ke otak. Akibatnya, emosi pun menyala dan daya kendali pun melumpuh. Hanya bila kadar serotin dalam otak seseorang pada kadar yang memadai, ia baru bisa berpikir sehat dan hidup normal. Pandangan ini secara langsung mengarah pula pada diri seseorang, taraf tinggi rendahnya kekerasan, ditentukan faktor gen atau keturunan.

Teori-teori kekerasan yang mendasarkan pada pengembangan pola pikir atas fenomena kekerasan kolektif atau kelompok, dapat ditunjukkan dengan keberadaan teori psikologis, teori instink, teori revolusi, teori konflik serta teori frustasi-agresi.

Dari berbagai kasus yang pernah ada di Indonesia bentuk-bentuk kekerasan yang terjadi dalam lingkup rumah tangga dapat dikelompokkan sebagai berikut:

Pertama, Kekerasan Fisik: a. Pembunuhan: 1. suami terhadap istri atau sebaliknya; 2 . ayah terhadap anak atau sebaliknya; 3. ibu terhadap anak atau sebaliknya (termasuk pembunuhan bayi oleh ibu); 4. adik terhadap kakak, kemanakan, ipar atau sebaliknya; 5. anggota keluarga terhadap pembantu; 6. bentuk campuran selain tersebut di atas. b. Penganiayaan: 1 . suami terhadap istri dan sebaliknya; 2. ayah terhadap anak dan sebaliknya; 3. ibu terhadap anak atau sebaliknya (termasuk penganiayaan bayi oleh ibu); 4. adik terhadap kakak, kemanakan, ipar atau sebaliknya; 5. anggota keluarga terhadap pembantu; 6. bentuk campuran selain tersebut di atas. c. Perkosaan: 1 . ayah terhadap anak perempuan; ayah kandung atau ayah tiri dan anak kandung maupun anak tiri; 2 . suami terhadap adik atau kakak ipar; 3. kakak terhadap adik; 4. suami atau anggota keluarga laki-laki terhadap pembantu rumah tangga; 6 . bentuk campuran selain tersebut di atas.

Kedua, Kekerasan NonFisik/Psikis/Emosional, seperti: a. penghinaan; b. komentar-komentar yang dimaksudkan untuk merendahkan dan melukai harga diri pihak istri; c. melarang istri bergaul; $d$. ancamanancaman berupa akan mengembalikan istri ke orang tua; e. akan menceraikan; f. memisahkan istri dari anak-anaknya dan lain-lain.

Ketiga, Kekerasan Seksual yang meliputi: a. pengisolasian istri dari kebutuhan batinnya; $b$. pemaksaan hubungan seksual dengan pola yang tidak dikehendaki atau disetujui oleh istri; c. pemaksaan hubungan seksual ketika istri tidak menghendaki, istri sedang sakit atau sedang menstruasi; d. memaksa istri menjadi pelacur atau sebagainya.

Keempat, Kekerasan Ekonomi yang meliputi: a. tidak memberi nafkah pada istri; b. memanfaatkan terhadap ketergantungan istri secara ekonomis untuk mengontrol kehidupan istri; c. membiarkan istri bekerja untuk kemudian penghasilannya dikuasai oleh suami, misalnya memaksa istri menjadi wanita panggilan.

Bentuk-bentuk tindak KDRT menurut UU Penghapusan KDRT tercantum dalam Pasal 6, Pasal 7, Pasal 8, dan Pasal 9 yaitu adalah:

Pertama, Kekerasan fisik adalah perbuatan yang mengakibatkan rasa sakit, jatuh sakit atau luka berat (Pasal 6 UU Penghapusan KDRT);

Kedua, Kekerasan Psikis, yaitu perbuatan yang mengakibatkan ketakutan, hilangnya rasa percaya diri, hilangnya kemampuan untuk bertindak, rasa tidak berdaya dan atau penderitaan psikis berat pada seseorang (Pasal 7 UU Penghapusan KDRT);

Ketiga, Kekerasan seksual, yaitu pemaksaan hubungan seksual yang dilakukan terhadap orang yang menetap dalam lingkup rumah tangga tersebut, adanya pemaksaan hubungan seksual terhadap salah seorang dalam lingkup rumah tangganya dengan orang lain untuk tujuan komersial atau tujuan tertentu (Pasal 8 UU Penghapusan KDRT); 
Keempat, Penelantaran rumah tangga juga dimasukan dalam pengertian kekerasan, karena setiap orang dilarang menelantarkan dalam lingkup rumah tangga, padahal menurut hukum yang berlaku baginya atau karena persetujuan atau perjanjian ia wajib memberikan kehidupan, perawatan atau pemeliharaan kepada orang tersebut. Penelantaran tersebut juga berlaku bagi setiap orang yang mengakibatkan ketergantungan ekonomi dengan cara membatasi atau melarang untuk bekerja yang layak di dalam atau di luar rumah, sehingga korban di bawah kendali orang tersebut (Pasal 9 UU Penghapusan KDRT).

\section{Penegakan Hukum terhadap Tindak Pidana Kekerasan yang Dilakukan oleh Suami terhadap Istri}

Di dalam Pasal 2 UU Penghapusan KDRT menegaskan lingkup rumah tangga dalam undangundang ini meliputi: pertama, suami, istri dan anak. Orang-orang yang mempunyai hubungan keluarga dengan orang sebagaimana dimaksud pada huruf a karena hubungan darah, perkawinan, persusuan, pengasuhan, dan perwakilan yang menetap dalam rumah tangga; dan kedua, orang yang bekerja membantu rumah tangga dan menetap dalam rumah tangga tersebut.

Selanjutnya, Pasal 4 UU Penghapusan KDRT mengatur tentang tujuan disusunnya undang-undang tersebut, yaitu penghapusan kekerasan dalam rumah tangga bertujuan untuk: a. Mencegah segala bentuk KDRT; b. Melindungi korban KDRT; c. Menindak pelaku KDRT; dan d. Memelihara keutuhan rumah tangga yang harmonis dan sejahtera.

KDRT adalah masalah sosial, bukan masalah keluarga yang perlu disembunyikan. Hal ini tertuang dalam aturan yang tercantum dalam Pasal 11 UU Penghapusan KDRT yang menegaskan pemerintah bertanggungjawab dalam upaya pencegahan KDRT.

\section{Peran Aparat Penegak Hukum}

Salah satu terobosan hukum yang dilakukan melalui UU Penghapusan KDRT adalah mengenai peran-peran aparat penegak hukum, khususnya kepolisian, advokat dan pengadilan dalam memberikan perlindungan dan pelayanan bagi korban KDRT terutama dengan diaturnya mengenai mekanisme perlindungan dari pengadilan demi keamanan korban.
Pertama, Peran Kepolisian (Pasal 16-20 UU Penghapusan KDRT). Saat Kepolisian menerima laporan mengenai kasus KDRT, aparat Kepolisian harus segera menerangkan mengenai hak-hak korban untuk mendapatkan pelayanan dan pendampingan.

Kedua, Peran Advokat (Pasal 25 UU Penghapusan KDRT). Advokat sebagai profesi yang membela masyarakat yang bermasalah atau berbenturan dengan hukum juga harus selalu siap dalam menyelesaikan masalah atau perkara mengenai KDRT. Hal ini diatur dalam Pasal 25 UU Penghapusan KDRT.

Ketiga, Peran Pengadilan. Peran Pengadilan dalam penyelesaian KDRT sangat dibutuhkan, sehingga UU Penghapusan KDRT tidak luput mengatur bagaimana peran pengadilan dalam memberikan perlindungan terhadap korban, khususnya mengenai pelaksanaan mekanisme perintah perlindungan.

\section{Fungsi dari UU Penghapusan KDRT}

Upaya untuk mengatur KDRT ke dalam suatu perundang-undangan melalui UU Penghapusan KDRT. Sanksi dari hukuman yang terdapat dalam UU Penghapusan KDRT juga berpengaruh untuk menjaga efektifitas dalam undang-undang tersebut. Dimana sebagai alat pemaksa agar seseorang mentaati, norma-norma yang berlaku.

Bab VIII tentang Ketentuan Pidana dalam Pasal 44 sampai dengan Pasal 46 UU Penghapusan KDRT mengemukakan sebagai berikut:

Pertama, Orang yang melakukan perbuatan kekerasan fisik dalam lingkup rumah tangga tersebut dalam Pasal 5 huruf a dipidana dengan pidana paling lama 5 (lima) tahun atau denda paling banyak Rp. 15.000.000,00 (lima belas juta rupiah).

Kedua, Jika perbuatan tersebut mengakibatkan korban mendapat jatuh sakit atau luka berat, dipidana dengan pidana penjara paling lama 10 (sepuluh) tahun atau denda paling banyak Rp. 30.000.000,00 (tiga puluh juta rupiah).

Ketiga, Apabila perbuatan tersebut mengakibatkan matinya korban, dipidana dengan penjara paling lama 15 (lima belas ) tahun atau denda paling banyak Rp. 45.000.000,00 (empat puluh lima juta rupiah).

Keempat, Jika perbuatan tersebut dilakukan oleh suami terhadap istri atau sebaliknya yang tidak menimbulkan penyakit atau halangan 
untuk menjalankan kekerjaan jabatan atau mata pencaharian atau kegiatan sehari-hari, dipidana dengan pidana penjara paling lama 4 (empat) bulan atau denda paling banyak Rp. 5.000.000, 00 (lima juta rupiah).

Selanjutnya, Pasal 45 UU Penghapusan KDRT mengandung makna:

Pertama, Bahwa orang yang melakukan perbuatan kekerasan psikis dalam lingkup rumah tangga dipidana dengan pidana penjara paling lama 3 (tiga) tahun atau denda paling banyak Rp. 9.000.000,00 (sembilan juta rupiah).

Kedua, Apabila perbuatan tersebut dilakukan oleh suami terhadap istri atau sebaliknya yang tidak menimbulkan penyakit atau halangan untuk menjalankan pekerjaan jabatan mata pencarian atau kegiatan sehari-hari, dipidana penjara paling lama 4 (empat) bulan atau denda paling banyak Rp. 3.000.000,00 (tiga juta rupiah).

Kemudian Pasal 45 ini, perlu dikaitkan dengan Pasal 52 dari undang-undang yang sama, yaitu tindak pidana kekerasan psikis sebagaimana dimaksud dalam Pasal 45 ayat (2) merupakan delik aduan.

Adapun Pasal 46 UU Penghapusan KDRT menegaskan, setiap orang yang melakukan perbuatan kekerasan seksual sebagaimana dimaksud pada Pasal 8 huruf a dipidana dengan pidana penjara paling lama 12 (dua belas) tahun atau denda paling banyak Rp. 36.000.000,00 (tiga puluh enam juta rupiah).

Pasal 46 tersebut berkaitan dengan Pasal 53 dari undang-undang yang sama, yaitu tindak pidana kekerasan seksual sebagaimana dimaksud dalam Pasal 46 yang dilakukan oleh seseorang terhadap istri atau sebaliknya merupakan delik aduan.

\section{Penanggulangan terhadap Tindak Pidana Kekerasan yang Dilakukan Suami pada Istri (Preventif dan Represif) \\ Sarana Penal}

Penggunaan upaya penal (sanksi/hukum pidana) dalam mengatur masyarakat (lewat perundangundangan) pada hakikatnya merupakan bagian dari suatu langkah kebijakan (policy). Mengingat keterbatasan dan kelemahan hukum pidana, maka dilihat dari sudut kebijakan, penggunaan atau intervensi penal seyogyanya dilakukan dengan lebih berhati-hati, cermat, hemat, selektif dan limitatif. Dengan kata lain, sarana penal tidak selalu dipanggil atau digunakan dalam setiap produk legislatif. Dalam menggunakan sarana penal Nigel Walker, pernah mengingatkan adanya prinsip-prinsip pembatas atau the limiting principles yang sepatutnya mendapat perhatian, antara lain: ${ }^{7}$

Pertama, jangan hukum pidana digunakan semata-mata untuk tujuan pembalasan; Kedua, jangan menggunakan hukum pidana untuk memidana perbuatan yang tidak merugikan atau membahayakan; Ketiga, jangan menggunakan hukum pidana untuk mencapai suatu tujuan yang dapat dicapai secara lebih efektif dengan saranasarana lain yang lebih ringan; Keempat, jangan menggunakan hukum pidana apabila kerugian atau bahaya yang timbul dari pidana lebih besar dari pada kerugian atau bahaya dari tindak pidana itu sendiri; Kelima, larangan-larangan hukum pidana jangan mengandung sifat lebih berbahaya dari pada perbuatan yang akan dicegah; dan Keenam, hukum pidana jangan memuat larangan-larangan yang tidak mendapat dukungan kuat dari publik.

Barda Nawawi Arief, menyimpulkan dan mengidentifikasi sebab-sebab keterbatasan kemampuan hukum pidana dalam menanggulangi kejahatan sebagai berikut: ${ }^{8}$

Pertama, sebab-sebab kejahatan yang demikian kompleks berada di luar jangkauan hukum pidana; Kedua, hukum pidana hanya merupakan bagian kecil (sub-sistem) dari sarana kontrol sosial yang tidak mungkin mengatasi masalah kejahatan sebagai masalah kemanusiaan dan kemasyarakatan yang sangat kompleks (sebagai masalah sosio-psikologis, sosio-politik, sosio-ekonomi, sosio-kultural dan sebagainya); Ketiga, keterbatasan jenis sanksi pidana dan sistem perumusan sanksi pidana yang bersifat kaku dan imperatif; Keempat, bekerja atau berfungsinya hukum pidana memerlukan sarana pendukung yang lebih bervariasi dan lebih menuntut biaya tinggi. Dalam memilih dan menetapkan (hukum) pidana sebagai sarana untuk menanggulangi kejahatan harus benar-benar telah memperhitungkan semua faktor yang dapat mendukung berfungsinya atau bekerjanya (hukum) pidana itu dalam kenyataan. Jadi diperlukan pula pendekatan fungsional; dan inipun merupakan pendekatan yang melekat pada setiap kebijakan yang rasional.

\footnotetext{
7 Barda Nawawi Arief, Beberapa Aspek Kebijakan Penegakan dan Pengembangan Hukum Pidana, Citra Aditya Bakti, Bandung, 1998, Op.Cit., h. 47-48.

${ }^{8}$ Ibid., h. 46-47.
} 


\section{Sarana Non Penal}

Berkaitan dengan usaha-usaha non-penal tersebut, Barda Nawawi Arief menyatakan bahwa mengingat upaya penanggulangan kejahatan lewat jalur non-penal lebih bersifat tindakan pencegahan untuk terjadinya, maka sasaran utamanya adalah menangani faktor-faktor kondusif penyebab terjadinya kejahatan. ${ }^{9}$ Faktor-faktor kondusif itu antara lain berpusat pada masalah-masalah atau kondisi-kondisi sosial yang secara langsung atau tidak langsung dapat menimbulkan atau dilihat dari sudut politik kriminal menumbuhsuburkan kejahatan. Dengan demikian secara makro dan global, maka upaya-upaya non-penal menduduki posisi kunci dan strategis dari keseluruhan upaya politik kriminal.

Menurut Muladi, dalam strategi preventif umumnya terdiri 3 (tiga) kategori yang mendasarkan diri pada public health model yakni: ${ }^{10}$

Pertama, Pencegahan kejahatan primer (primary prevention). Strategi yang melalui kebijakan sosial, ekonomi dan kebijakan sosial yang lain, secara khusus mencoba mempengaruhi kriminogenik dan akar kejahatan. Hal ini misalnya saja melalui pendidikan, perumahan, lapangan kerja dan rekreasi yang sering disebut sebagai pre offence intervention. Target utamanya adalah masyarakat umum bersifat luas.

Kedua, Pencegahan sekunder (secondary prevention). Dapat ditemukan dalam sistem peradilan pidana dan penerapannya secara praktis seperti peranan polisi dalam pencegahan kejahatan. Targetnya adalah mereka yang cenderung melanggar.

Ketiga, Pencegahan tersier (tertiary prevention). Terutama diarahkan pada residivisme oleh polisi atau lembaga-lembaga lain sistem peradilan pidana. Targetnya adalah mereka yang telah melakukan kejahatan. Dibedakan pula yaitu: a. Pencegahan sosial (sosial crime prevention). Diarahkan pada akar kejahatan; b. Pencegahan situasional (situational crime prevention). Diarahkan pada pengurangan kesempatan untuk melakukan kejahatan; c. Pencegahan masyarakat (community based prevention). Dilakukan dengan tindakantindakan untuk meningkatkan kapasitas masyarakat untuk mengurangi kejahatan dengan meningkatkan

\footnotetext{
${ }^{9}$ Muladi dan Barda Nawawi Arief, Bunga Rampai Hukum Pidana, Alumni, Bandung, 1992, Op.Cit., h. 49.

${ }^{10}$ Ibid., h. 8 .
}

kemampuan masyarakat untuk menggunakan kontrol sosial informal. ${ }^{11}$

\section{Hambatan Terhadap Penanganan Kekerasan yang Dilakukan oleh Suami terhadap Istri}

Tindakan KDRT yang terjadi mempunyai sifat istimewa dan khusus. Keistimewaan perbuatan ini terletak pada hubungan antara pelaku dan korban. Pada kasus-kasus tindak pidana yang lain kadangkadang pelaku tidak mengenal korban sama sekali dan seringkali tidak mempunyai hubungan. Tetapi pada KDRT pelaku dan korban mempunyai hubungan khusus yaitu hubungan perkawinan (suami istri), hubungan darah (orangtua, anak, kemenakan) atau hubungan adanya ikatan kerja misalnya pembantu rumah tangga dan tinggal dalam satu rumah dengan pelaku.

Masyarakat Indonesia merupakan masyarakat yang mengutamakan kekeluargaan. Keutuhan rumah tangga merupakan hal yang penting. Apabila di dalam rumah tangga itu terdapat masalah, selama masih bisa diselesaikan dengan cara kekeluargaan, jalan inilah yang akan dipilih. Rasa malu apabila keburukan rumah tangga diketahui orang serta pengabdian seorang istri terhadap suami masih mendominasi rumah tangga di Indonesia. Kaum feminis sering menuding nilai-nilai ini yang melanggengkan KDRT. Namun inilah kenyataannya. Di dalam masyarakat telah ada aturan-aturan yang tidak begitu saja dapat diubah hanya dengan munculnya sebuah undangundang.

Sebuah dilema yang tidak mudah dicarikan jalan keluarnya. Disatu sisi KDRT tetaplah sebuah kekerasan, sebuah tindakan yang menimbulkan korban, negara telah menentukan bahwa pelakunya dapat dipidana. Disisi lain apabila pelaku dipidana, keluarga akan menanggung malu, keutuhan rumah tangga terancam, akan ada proses peradilan yang panjang dan berlarut-larut. Apabila pelaku adalah pencari nafkah dalam rumah tangga itu, keluarga akan kehilangan pencari nafkah utama. Hambatanhambatan tersebut adalah:

Pertama, korban tidak mengetahui bahwa tindakan kekerasan yang dilakukan oleh suami merupakan pidana atau perbuatan yang dapat dihukum. Oleh karena itu, korban tidak melaporkan tindak kekerasan yang dialaminya;

${ }^{11}$ Ibid. h. 8 . 
Kedua, korban membiarkan tindakan kekerasan terhadap dirinya sampai berlarut-larut. Hal ini bisa disebabkan oleh korban berpendapat tindakan suaminya akan berubah;

Ketiga, korban berpendapat apa yang dialaminya adalah takdir atau nasibnya sebagai istri. Hal ini dapat terjadi karena adanya pendapat bahwa seorang istri harus bekti (setia dan mengabdi) pada suami;

Keempat, korban mempunyai ketergantungan secara ekonomi pada pelaku tindak kekerasan. Ketidakberdayaan finansial yang dimaksud adalah kondisi istri yang tidak mandiri dan tidak memiliki penghasilan sehingga jika ia melakukan tindakan dan akibat tindakannya tersebut sang suami meninggalkannya atau dijatuhi sanksi pidana maka sang istri tidak dapat menghidupi dirinya dan anakanaknya;

Kelima, korban mempertahankan status sosialnya, sehingga kalau sampai tindak kekerasan yang terjadi dalam rumah tangganya diketahui oleh orang lain, akan memperburuk status sosial keluarganya dalam masyarakat. Sehingga korban merasa perlu melindungi nama baik keluarganya terutama pelaku berasal dari kalangan keluarga bersangkutan;

Keenam, korban takut akan ancaman dari suami. Rasa takut yang dimaksud adalah ketakutan para istri untuk menceritakan apalagi melaporkan perlakuan yang diterimanya, biasanya karena para suami memberikan ancaman akan melakukan tindakan yang lebih kejam jika ada yang mengetahuinya. Rasa ketakutan wanita terhadap kekerasan juga lebih besar dari pada laki-laki, inilah yang menjadi kendala dalam masalah KDRT ini muncul kepermukaan terlebih lagi terselesaikan dengan benar. Korban merasa proses pidana terhadap kasus ini belum tentu membuat pelaku dipidana. Korban khawatir akan membalas dari pelaku tindak pidana kekerasan tersebut, terlebih pelaku merupakan orang yang dekat dengan korban dalam rumah tangga tersebut;

Ketujuh, korban khawatir keluarga akan menyalahkan dirinya karena dianggap tidak dapat menyelesaikan masalah rumah tangganya sendiri;

Kedelapan, korban terlambat melaporkan tindakan kekerasan yang dialami, sehingga buktibukti fisik sudah hilang.

Hambatan dapat dilakukan oleh keluarga korban, karena KDRT adalah aib keluarga yang harus ditutupi agar tidak diketahui oleh masyarakat. Alasan yang lain adalah karena tindak KDRT merupakan urusan domestik atau urusan intern keluarga;

Hambatan yang lain datang dari masyarakat. Memang masih ada pendapat yang menganggap kekerasan yang dilakukan oleh suami terhadap istri adalah urusan keluarga bukan merupakan kejahatan yang dapat diselesaikan melalui jalur hukum. Pendapat demikian masih mewarnai berbagai kalangan dalam masyarakat, sehingga akan merupakan hambatan bagi penegak hukum di bidang tindak KDRT. Hambatan dari Negara:

Pertama, hambatan ini berupa ketentuan bahwa biaya visum et repertum harus dikeluarkan oleh korban. Bagi korban yang tidak mampu, hal ini merupakan hambatan dalam mencari keadilan; Kedua, selain itu dimasukannya kekerasan fisik, psikis dan seksual yang dilakukan oleh suami terhadap istri, ke dalam delik aduan, sangat membatasi ruang gerak istri. Meskipun dalam undang-undang tidak disebutkan delik aduan absolut atau delik aduan relatif tetap saja menempatkan istri pada posisi subordinatif. Hal ini tercantum dalam Pasal 51, 52, dan 53 UU Penghapusan KDRT. Padahal pada awalnya sudah ditentukan bahwa KDRT merupakan suatu delik, suatu perbuatan pidana yang dapat diproses secara hukum.

\section{Penerapan Ancaman Pidana Penjara dan Denda serta Tambahan}

Tercatat sejumlah sanksi pidana penjara antara 6 bulan hingga 2 tahun 6 bulan. yang telah diputuskan oleh Pengadilan Negeri dengan menggunakan pasalpasal UU Penghapusan KDRT diantaranya Pasal 49 jo Pasal 9 dan Pasal 279 KUHP untuk tindak penelantaran dan suami menikah lagi tanpa ijin istri; Pasal 44 untuk tindak kekerasan fisik; pasal 45 untuk tindak kekerasan psikis berupa pengancaman. Sedangkan putusan Pengadilan dengan sanksi pidana penjara yang lebih tinggi hingga 6 tahun diputuskan terhadap sejumlah kasus dalam relasi KDRT, yang didakwa dan dituntut dengan menggunakan pasalpasal KUHP (Pasal 351, 352, 285, 286 jo 287, 289, dan 335 untuk kasus penganiayaan anak dan perkosaan anak); Pasal 81 dan 82 UU Penghapusan KDRT dan Pasal 287 dan 288 KUHP untuk kasus perkosaan anak. Belum ditemukan tuntutan yang menggunakan ancaman pidana penjara atau denda maksimal sebagaimana yang diatur dalam UU Penghapusan KDRT ini. 
Hingga kini belum ada putusan Pengadilan yang menjatuhkan hukuman pidana tambahan terhadap pelaku KDRT sebagaimana yang diatur oleh UU Penghapusan KDRT. Pasal 50 UU tersebut mengatur, selain pidana sebagaimana dimaksud, hakim dapat menjatuhkan pidana tambahan berupa: a. pembatasan gerak pelaku baik yang bertujuan untuk menjauhkan pelaku dari korban dalam jarak dan waktu tertentu, maupun pembatasan hak-hak tertentu dari pelaku; b. penetapan pelaku mengikuti program konseling di bawah pengawasan lembaga tertentu.

\section{Penerapan Perlindungan terhadap Korban oleh Pengadilan}

Pengadilan sebagaimana diatur dalam Pasal 28 sampai dengan Pasal 38 UU Penghapusan KDRT. Ketua Pengadilan wajib mengeluarkan surat penetapan yang berisi perintah perlindungan tersebut dalam tenggang waktu 7 (tujuh) hari sejak diterimanya surat permohonan kecuali ada alasan yang patut (Pasal 28). Permohonan tersebut dapat disampaikan dalam bentuk lisan atau tulisan.

Pasal 29 UU Penghapusan KDRT ini mengatur, permohonan untuk memperoleh surat perintah perlindungan dapat diajukan oleh: a. korban atau keluarga korban; b. teman korban; c. Kepolisian; d. relawan pendamping; atau e. pembimbing rohani.

Bentuk perlindungan hukum ini juga belum banyak dikenal dan diterapkan oleh para penegak hukum dan dimanfaatkan oleh masyarakat. Berdasarkan pemantauan LSM hingga tahun 2008 ini, baru satu Pengadilan Negeri di Jawa Tengah yang telah beberapa kali mengeluarkan surat penetapan perintah perlindungan bagi korban, dan memprosesnya dalam tenggang waktu kurang dari 7 (tujuh) hari.

\section{PENUTUP}

\section{Kesimpulan}

Penegakan hukum terhadap tindak kekerasan yang dilakukan oleh suami terhadap istri dapat ditanggulangi dan diminimalisir dengan cara pencegahan sesuai Pasal 4 UU Penghapusan KDRT, serta adanya peranan penting dari aparat penegak hukum khususnya Kepolisian, Advokat dan Pengadilan dalam memberikan perlindungan kepada korban.

\section{Rekomendasi}

Berdasarkan hasil analisis dalam pembahasan yang telah dilakukan, maka pada penelitian ini dapat disampaikan beberapa saran sebagai berikut: a. Aparat penegak hukum dalam pemberian sanksi pidana sesuai dengan ketentuan UU Penghapusan KDRT; b. Pemerintah, aparat penegak hukum maupun masyarakat ikut berpartisipasi secara aktif dan bertanggungjawab terhadap masalah perlindungan hukum, bagi korban kekerasan yang dilakukan oleh suami terhadap istri.

\section{DAFTAR PUSTAKA}

\section{Peraturan Perundangan-undangan:}

Undang-Undang Nomor 1 Tahun 1974 tentang Perkawinan.

Undang-Undang Nomor 23 Tahun 2004 tentang Penghapusan Kekerasan dalam Rumah Tangga.

Kitab Undang-Undang Hukum Pidana (KUHP).

\section{Buku:}

Adi, Rianto. 2004. Metodologi Penelitian Sosial dan Hukum. Edisi I. Jakarta: Granit.

Arif, Barda Nawawi. 1998. Beberapa Aspek Kebijakan Penegakan dan Pengembangan Hukum Pidana. Bandung: Citra Aditya Bakti. 2000. Kebijakan Legislatif dalam Penanggulangan Kejahatan dengan Pidana Penjara. Semarang: Badan Penerbit Universitas Diponegoro.

Komisi Nasional Anti Kekerasan terhadap Perempuan. 2007. Catatan Tahunan tentang Kekerasan terhadap Perempuan. Jakarta, 7 Maret 2007.

Muladi dan Barda Nawawi Arief. 1992. Bunga Rampai Hukum Pidana. Bandung: Alumni.

Soeroso, Hadiati Moerti. 2010. Kekerasan dalam Rumah Tangga. Jakarta: Sinar Grafika.

Suaedy, Ahmad. 2000. Kekerasan dalam Perspektif Pesantren. Jakarta: Grasindo.

\section{Website:}

http://lib.atmajaya.ac.id/default. aspx $?$ tabID $=61 \& \operatorname{src}=a \& i d=210509$, akses tanggal 18 Maret 2013.

http://www.lbh-apik.or.id/fact-58.htm/, diakses 20 Maret 2013. 